\title{
Federalism as a Factor of Sustainable Development of the Multiethnic State
}

\author{
Helen Karsanova
}

Ph.D. (Doctor of Political Science), Odintsovo University for the Humanities, Moscow region, Russia

Email: e_karsanova@mail.ru

\section{Doi:10.5901/mjss.2015.v6n3s2p582}

\begin{abstract}
Problems of preservation of territorial integrity of the multiethnic states and safety in the sphere of the interethnic relations demand not only comprehensive study of modern ethnopolitical processes, but also search of effective mechanisms of response to their calls and risks. In the context of modern inconsistent development of the multiethnic state could such a mechanism be the federalism? This article is an attempt to answer this question.
\end{abstract}

Keywords: federalism; interethnic relations; multiethnic state; ethnopolitical contradictions and conflicts.

\section{Introduction}

On the one hand, experience of the state construction of such countries as Switzerland and Belgium confirms ability of federalism to level ethnopolitical conflicts in the multiethnic states, on the other hand, failures of federal experiments in the USSR and Yugoslavia showed ability of federalism to aggravate interethnic and ethnoconfessional contradictions, and fragmentariness of multiethnic society as well as to provoke international intensity. In other words, the federalism as a form of the state arrangement of multiethnic society appeared in obviously overloaded semantic situation and began to be perceived by one as a source of all troubles, and by others as a panacea from all ethnopolitical problems.

\section{International Experience of Federal Practices}

"March of federalism" began the procession in the middle of the last century. Disintegration of the colonized territories not always took place on ethnic, linguistic and religious principles, which objectively led to formation of the multiethnic states. Federalization of the states in this situation acted as the most acceptable way of the solution of ethnopolitical problems. The dominating impact on federalization of many countries was made by ethnoconfessional factors. New federations appeared on the political map of the world from 1950 till 1960: Malaya (later - Malaysia), Indonesia, India, Federation of Rhodesia and Nyasaland, Nigeria, Pakistan, West Indies, Federation of Mali and some other federations (Karsanova, 2010, p.218).

The demand for ideas of federalism was reflected in constitutions of already existing federal states - like Brazil and Argentina. New federal constitutions were adopted in 1948 in Venezuela, in 1949 in the Western Germany. In Eastern Europe after World War II there were socialist federations of Yugoslavia and Czechoslovakia.

The federal device was imposed to some countries by the mother country and as time showed, the realization of the federal principles didn't become a guarantee of a sustainable development of the young states. Within a rather short term Cameroon, Indonesia, Rhodesia and Mali passed to the unitary form of government. Serious shocks accompanied federal history of Pakistan, Indochina, Burma. In India and Nigeria territorial integrity managed to be kept by using the weapon only.

Ethnopolitical and socioeconomic problems in steady federations provoked further discredit of the federal forms of government. So, in Canada the situation around Quebec (1970) became aggravated, in Switzerland destabilization was connected with a territory exit of Jura from the Canton of Bern, in Australia (1975) as a result of the constitutional crisis the question about introductions of the republican form of government was seriously discussed, in 1969 in Germany disagreements between lands and the federal government became aggravated. Disintegration of the Soviet Union, Yugoslavia and binational Czechoslovakia became a serious motive to reevaluate the federalism which is even more often considered as an unstable form of the state arrangement. Preston King fairly noticed: "History of federations, at least, equally, is a history of success and defeats" (King, 1993, p.97). And indeed, on the modern political map of the world it is possible to find examples of already settled, steadily developing federations, including, multiethnic. USA and 
Switzerland are the good examples.

\subsection{European federalism}

It is possible to call the second half of the XX century the national liberal movements rise in the world. Events in the Canadian Quebec created conditions for registration of the "francophone" movement in the international organization inspired by idea to preserve French language and culture. French-speaking Quebec, Bernese Jura, the Italian region of Aost and the Belgian Wallonia demanded the expansion of the autonomy rights.

In Switzerland stabilization of an ethnopolitical situation began with the amendments to "language article" in the Constitution of Switzerland (1996). Now the constitution not only recognized four languages at the state level, but also obliged the federal authorities to undertake the measures promoting ethnocultural integration of the Swiss regions. Pertinently to note that functionality of the Swiss federalism in many respects is explained by practice of "referendum democracy" which can be considered from the point of view of subsidiary of democratic process and as the monitoring system of citizens over activity of public authorities. In the Swiss federal project the emphasis is put not on the ethnic, but on the cantonal identity and democratic integration that according to V.A. Tishkov's remark "helps to keep a language and religious variety. Here the democracy is included as an element in the federal structure, and not vice versa, for protection of interests of minorities in multicultural society. ... Therefor the federalism and democracy are initially connected with each other" (Tishkov, 2005, p.164).

It is known that in Switzerland there is no head of state. Its functions are executed by Council of Confederation which all seven members serially within a year are executed by presidential powers. The similar system of public administration was developed in Yugoslavia in 1980-1991. However, in Yugoslavia in the state presidium all eight republics and provinces were represented, while in Switzerland at the federal level not cantons, but parties of grand coalition are presented. Thus the rule is strictly followed - not less than two members of council of Confederation have to be French-speaking and one Italian-speaking. The Swiss Constitution of 1999 allocates cantons with extensive powers in the ethnocultural sphere which is an internal affair of cantons. Therefore we can't really talk about the state ethnolinguistic policy. Such situation distinguishes the Swiss federation from many other multiethnic federations. Moreover, there is no need for international communication language, and in this regard Switzerland can't be an example for many multinational states, including Russia as there is an objective need for international communication language.

It is quite obvious that the Swiss federal project can't be mechanically copied for the prevention of ethnopolitical conflicts by other multiethnic states. Experience of federal construction of Switzerland is valuable as it calls into question ideas about possibility of achievement of internal political balance only by the uniform states creation in the ethnic relation. Functionality of a constitutional political system of the Swiss state is an essentially important argument in favor of the real opportunities of federalism for ethnic rapprochement and frictionless interaction of the large ethnolinguistic majority with other linguistic groups.

Giving the most general characteristic of the types of federalism which have been developed in the modern Europe we can name the states in which federal lines are in a varying degree inherent, it is Belgium, Italy, Spain and partly France.

Certain political "ground" where today limits and possibilities of modern federalism are approved is modern Belgium as its experience can serve as an example for the European Union to real possibility of harmonious coexistence and development of multicultural political association acts. In Belgium there are equal linguistic communities - Flemish, French-speaking (francophone) and German-speaking. Proceeding from it, the territory of the country was divided into four regions: Flanders, Wallonia, Brussels and region of the German-speaking population. In January, 1989, after reorganization, the central government delegated to regions rather extensive range of powers in various spheres of management. Having reserved powers in the field of the international intercourses, defense, external and internal security, finance and currency policy, the Belgian government questions of a social and economic range, health care, education and culture, transferred to the jurisdiction of regions and communities. In 1994 Belgium after adoption of the new Constitution de facto became federation. The regional and linguistic principle of the political and territorial device, redistribution of powers between the center and regions in favor of the last, it was reflected in structure of the government of Belgium.

In a basis of formation of the government the linguistic parity principle was underlain. During political modernization of the country questions of competence of the Center, Communities and regions were repeatedly specified and though this process isn't complete to this day, it is obviously possible to designate the volume of the powers received by the provincial authorities for the last decades. In general redistribution of powers between the central and regional authorities on economic problems keeps within the thesis: "independence without damage to the uniform state". The center partially 
subsidizes regional economy "lagging behind", for the purpose of prevention of a situation when weak regions exist at the expense of more successful economically regions. But, as showed time, this principle didn't work as the main argument of Flemish separatists is just the fact of dating of Wallonia at the expense of the means received by the state budget from Flanders.

There are disputable questions of the status of Brussels-Hal-Vilvorde - the all-federal constituency on which partition on ethnolinguistic border Flemings, and also the international cooperation of regions and border territories insist. The question of powers of authority in the bilingual Brussels capital region which territorially is located in Flanders is the most challenged, but thus is allocated with French-speaking orientation. For the solution of this problem the following scheme was approved: elections to Council pass according to two language lists corresponding to a linguistic proportion of the residents of Brussel. Here it is important to note that the capital parliament makes all decisions on the basis of consensus. At the same time, the structure of different levels of the power in Brussels (Council and two Communities), complicates work of the Belgian government which has to face and resolve the conflicts between representatives of various administrative-territorial educations. In other words, the capital region, with its incoincident ethnolinguistic and geographical boundaries, continues to remain the territory of search of a compromise between various parties of the ideological and political and ethnic contents. Social and economic contradictions against permanent interparty crises, instability of authority of a monarchy, can potentially lead to an aggravation of ethnopolitical contradictions in the country. In the conditions of the dominating influence of Flemish national separatists, ethnoconflict factors have every chance "to work". Today in Belgium projects about a political and territorial reorganization of the country continue to be discussed: about reunion of Holland and Flanders, about possibility of inclusion of Wallonia in structure of France.

Thus, now the question that Belgium successfully managed to solve a number of ethnopolitical and ethnolinguistic problems raises more doubts, than confidence. At the same time, at all discrepancy of modern ethnopolitical processes, federalization of the country, redistribution of powers of authority from the Center to the region was succeeded to keep integrity of the Belgian state, the first stage for the account. Who from the carried-out reforms appeared in bigger benefit Flemings or vallonets difficult to define. Important another - the existing ethnopolitical contradictions by federalization of the country were institutionalized and moved to "field" of parliamentary debates, having excluded thereby possibility of armed conflicts or terrorist activity which examples were shown in due time by the Basque Country and Northern Ireland.

In search of the solution of national problems Belgians elected the principle of democratic consensus taking into account regional, political and linguistic interests of participants of ethnopolitical process. Thus both the Center and regions were focused to resolve controversial issues only in negotiation process and in a legal framework. It is indicative that after country federalization, there are a lot more unresolved problems, but none of national communities of Belgium intend to come back to unitarianism.

On the political map of modern Europe it is possible to find the states which in their structure combine features of both federal and unitary state. Most often such states are called regional. "Constitutional regionalization" became result of the administrative reforms which were carried out in Italy after World War II. In Italy from 1948 to 1963 five autonomous regions were formed (subsequently their number increased) possessing powers in rather large volume. Italian regions which, in turn, are divided into provinces and communes, elect bodies allocated with legislative, executive and administrative and other functions. In process of introduction of new administrative-territorial division Italy began to look like rather a federal state, than a unitary one. Constitutional laws adopted in the 1970th and in 2001, expanded a circle of powers of regions giving local administration even bigger independence. Despite contradictions between North, Center and South and the conflict of interests between various political parties of Italy, most likely, the constitutional regionalization in the long term would be displaced by country federalization.

Domination of federal trends can be seen on the example of Spain, which is "de jure the unitary state, and "de facto", despite the absence of this term in the Spanish constitution of 1978, a federation. Noteworthy the idea of federalism in Spain is unpopular as is associated with separatism and threat for political and territorial integrity of the state.

The organization of political-territorial administration in Spain according to the Constitution is based on the principles of unity of the state and recognition of autonomy of regions. So constitutionally there are two levels of powerscentral and of territorial autonomies having its authorities, institutes and funding. The status of Spanish autonomies is various and classified as:

a) Autonomous territories allocated with special status (Andalusia, an autonomy Navarre), partly Canary Islands and Valencia (finally the status isn't specified);

b) Catalonia, the Basque Country and Galicia - autonomies with the status of "a special historical Spanish nationality". These autonomies have the expanded volume of the rights and powers;

c) Eleven territories of the country having strictly outlined range of competences which can be expanded only 
after five years of existence of an autonomy within these powers.

Each of 17 autonomous communities of Spain has the right to adopt local laws, to create local governing bodies whose activity is under control of the Government, Constitutional court and Audit Chamber.

With ethnopolitical situation in Spain today it is theoretically possible to allow withdrawal of certain regions from the structure of uniform Spain. But practically it is hardly possible as neither internal, nor international factors are in favor of the development of such scenario. Precepts of law of the European Union don't allow certain regions which separated from member countries of the Union to join it. The decision of parliament of Spain to reject the offer of holding a referendum on independence of Catalonia, didn't remove from the agenda the necessity of the solution of Catalan question. However, on the one hand, the ban is constitutionally imposed on the federal project in Spain: "By no means is the federation of autonomous communities allowed" (The constitution of Spain, Art. 145), and on the other hand, the Spanish model of autonomies ceases "to work". In the conditions of current political tendencies, it is most likely to expect another constitutional reform involving modification of the legal statuses of autonomies that, in fact, will mean country federalization, to be held.

\subsection{Russian model of federalism}

Feature of the modern Russian Federation are significant ethnic, confessional and ethnolinguistic distinctions between regions. Despite a pronounced mononational and monoconfessional basis (80\% - Russians; 66-67\% - Orthodox Christians), in our country about 200 nationalities speaking 100 languages and dialects (Federal State Statistics Service, http:www gks.ru). Russia often designate "ethnic federation" (Stolyarov, 2008, p.469). Existence of the ethnoconfessional territories sharply different from the main part of the country, and also a combination of the national and territorial principle of the organization of a federal state, create conditions for ethnicity politicization, provoke the high level of interethnic intensity. The modern multiethnic Russian society not only isn't "the multinational Russian nation", but also "moves to the opposite side" (Pine, 2009, p.116). At the same time expediency of the constitutional introduction of the new model of federalism formed on the American sample on the administrative-territorial beginnings in modern conditions of "fragmentary modernization" of the Russian state, not only is doubtful, but also is dangerous, from the point of view of preservation of the national and state integrity of Federation. Therefore improvement of the federal relations, establishment of right balance "center regions" continues to remain one of the most priority problems of the Russian Federation.

Modern ethnopolitical processes in Russia are a consequence of almost centenary national policy of the Soviet state. Result of October revolution of 1917 became formations of RSFSR, and then the Soviet Union (1924). The USSR structurally represented four-level federation: federal republic, autonomous republic, autonomous region or autonomous area. Political and territorial demarcation of borders was quite often carried out on the basis of the forcible and tactical principles, and the right of the federal republic of free secession of the Union affirmed in the Constitution of the USSR of 1977 was only the declaration. Redrawing of administrative-territorial borders, the section of ethnically close people with their inclusion in different subjects of federation, deportation of the whole people and mass repressions are obvious gross blunders of the Soviet national policy. Unlike the imperial government of Russia, the Soviet power could keep all people which it "accepted" at the time of creation of the USSR. At the same time, the repressive and unreasoned national policy practiced within the Soviet federation became a source of the ethnopolitical contradictions and armed conflicts which became aggravated by 1992. And consequences of radical and painful socio-political transformation after collapse of the USSR are notable in Russia to this day.

Signing of bilateral Federal contract between the federal center and regions abruptly raised the degree of their political independence. After introduction of direct elections of heads of territorial subjects of the Russian Federation, federal center began to lose real opportunity to control political situation in the regions. In 2000 the Head of state initiated the administrative and state reform. The main objective of this reform was strengthening vertical power by means of establishing institute of plenipotentiaries of the Russian President and federal districts. It was followed by another reform - change of order of formation of the Federation Council of the Russian Federation (2001). Dismissal of heads of legislative and executive power of territorial subjects of the Russian Federation from participation in the upper house of parliament strengthened position of the federal center, having given it opportunity of political influence on the Federation Council. After tragic events of 2004 in the city of Beslan of the Republic of Northern Ossetia-Alania direct elections of governors were cancelled, and powers of representatives of the Russian President in federal districts expanded. Without any resistance from regional elite, lack of the political competition allowed the Center could in short time completely change the relations between the center and regions. Subjects of Federation, partially lost opportunity to play an independent political role, having turned into objects of the centralized management. In other words, in order to make 
contractual relations in federation mutually beneficial it is necessary not only to have stable state institutes, but also legitimate "rules of the game". Without taking this remark into consideration, difficulties of formation of federalism in Russia will be hardly clear.

Figuratively as the Russian scientists say today "the Russian model of federalism drifts towards "strengthening of unitary or imperial elements" and can remain "only "paper" constitutional principle" (Busygina, Filippov, 2010). Russian political scientist Andrey Zakharov called Russia a "unitary federation" (Zakharov, 2010), and the British researcher Cameron Ross a «federation without federalism" (Ross, 2002, p.7).

In this connection, it is important to emphasize that federalism is always a process. And even imperfect, strictly not keeping within a framework of classical understanding, the Russian model of federal relations, unlike other forms of a state system, reduces risk of appearance of ethnic regionalism and separatism which is aggravated with globalization processes and increases chance of development of the multiethnic state on a democratic way. And in Russia there is no task more actual, than this.

Despite specific features in the heart of Russian and West European models of federalism there are more common features, than distinctions. First, both the Russian Federation, and the most part of the European federations emerged from fragments of large empires of the Romanovs, the Habsburgs, the Hohenzollerns. Secondly, domination of center over regions, characteristic to any imperial state, found practical application not only in Russia and countries of Western Europe, but in construction of a political structure of modern European Union. Certainly, development conditions, and also ideas of inalienable human rights in these federations were different. Thirdly, the mentioned federal projects are identical from the point of view of the developed and introduced " top construct" (Zakharov, 2008, p.108). Thus the American project of federalism focused only on "the self-defined individual" (Zakharov, 2008, p.108) and emerged "from below", differs from the Russian and European experience of creation of national models of federalism.

\section{Conclusion}

In the states with the polietnichny population which is compactly living in historically developed territory, federalism is capable to play an important role in the solution of ethnic question. It goes without saying that federalism itself isn't capable to resolve this issue as it depends on many other factors that could be of more importance (for example, from democratic character of the state and observation of human rights in it). But it is impossible to underestimate the role and value in it of a federations as one of state legal form of solving the national question. At a certain stage of the historical development many ethnoses have a need for some state isolation allowing to accelerate their internal consolidation, for better preservation of identity of each ethnos, its language, culture, traditions, customs, etc. The federation allows to satisfy this historical requirement and at the same time to keep unity and territorial integrity of the multinational state. Of course, creation inside one state (federation) of the state components inevitably complicates its structure, creates additional problems and can cause danger of etnocratic separatism. But these additional difficulties and expenses are overlapped by huge positive effect which can be received from use of the principle of federalism in harmonization of inter ethnic relations in the country.

It should be noted, that speaking about a number of multiethnic federations as about the states which are in a condition of ethnopolitical instability one can find that after their disintegration it is exactly federalism that for many decades acted as the effective mechanism of regulation of the interethnic relations and contradictions, without allowing developing them into "open" conflicts. International federal practices do not show the ability of federalism to completely eliminate interethnic contradictions and the conflicts in the multiethnic state, but quite convincingly proves the opportunity to transform an ethnopolitical tension to such form which gives real opportunities for the solution of controversial issues only in negotiation process. Federalism in its progressive form doesn't contradict neither ideas of the sovereignty of the state, nor the right of self-determination of the people, interests of regions in their aspiration to increase independence. The federal structure of the state allows considering much more national features and problems of regions, than at centralization of the power of the unitary state, as preservation of regional and ethnic variety is a traditional task and function of federalism.

In view of all characteristics which were given to federalism, it is possible to claim that federalism itself can act as the most effective remedy of preservation of the territorial integrity of the multiethnic state and provide the safety mode in the sphere of the interethnic relations. The higher the degree of institutionalization of democratic board in the multiethnic state, the more vivid are the conflict solving functions of federalism. 


\section{References}

Busygina I., Filippov M. Return of federation: Price of imperial federalism. Newspaper of the Sheet 03.02.2010,18(2536) http://www. vedomosti.ru/newspaper/article/2010/02/03/224490

Constitution of Spain. Well: http://www .domeuropa.eu/rest/23-fales/50-konstitucziya-ispanii? showall=1

Federal State Statistics Service. Well: http://www gks.ru

Karsanova E.S. Thesis of the doctor of political sciences: "Ethnopolitical conflicts in multiethnic federations: the nature and practice of the decision in the conditions of globalization. - M, 2012.

King P. Federation and Representation//Comparative Federalism and Federation/M. Burges, A. Gagnon (eds.). - Hempstead Harvester: Wheatsheaf, 1993.

Stolyarov M. V. Theory and practice of federalism. A course of lectures about a federal state. M, 2008. Page 469.

Pine of E.A. Rasputits: Polemic reflections about predefiniteness of a way of Russia. M, 2009.

Ross K. Federalism and Democratization in Russia. Manchester: Manchester University Press, 2002.

Tishkov V.A. Etnopolitichesky federalism: Russian and international experience//Tishkov of V.A. Etnopolitologiya and politician. M, 2005.

Zakharov A. Unitary federation. Five etudes about the Russian federalism. — M.: Moscow school of political researches. 2008.

Zakharov Andrey. The Russian federalism as the "sleeping" institute//"Emergency ration". 2010. №. 3. 